\title{
Environmental Impact of Flooding in the Main (Smallwood) Reservoir of the Churchill Falls Power Plant, Labrador, Canada. I. Background and Descriptions of Flooded Conditions Related to Vegetation and Land Cover Types
}

\author{
Denes Bajzak ${ }^{1}$, Bruce A. Roberts ${ }^{2}$ \\ ${ }^{1}$ Retired Professor of Faculty of Engineering and Applied Science, \\ Memorial University of Newfoundland and Labrador \\ ${ }^{2}$ Retired Sr. Research Scientist, Natural Resources Canada, \\ Canadian Forest Service, Corner Brook, Newfoundland \& Labrador. Presently Ecologist and Chairperson, \\ Pigugunnatunik Kaujisatik amma katimattisiji, Torngat Wildlife \& Plants Co-management Board, The \\ Torngat Secretariat, P.O. Box 2050, Station B, Happy Valley-Goose Bay, NL, A0P 1E0, \\ E-mail: bajzak.denes@yahoo.ca, bar@nl.rogers.com \\ Received November 24, 2010; revised December 28, 2010; accepted January 25, 2011
}

\begin{abstract}
This paper, the first in a series provides the background of the project, reports on the early phases of construction with the descriptions of the pre and post flooded conditions related to vegetation and land cover types surrounding the reservoir. Currently there are plans to develop the so called "Lower Churchill Area" by establishing new power plants at Gull Island and at Muskrat Falls with associated reservoirs. These new plants would use the discharged water of the plant from Churchill Falls and the additional water collected from some of the Churchill River Basin. The information provided by these papers could have relevance to the environmental evaluation of these new developments. The Churchill Falls Hydro Project (called the "Upper Churchill Development") in Labrador, Canada, was initiated in the late 1960s and the 5428-MW hydro generating plant constructed was then among the largest in the world. At that time, in general, not much attention was paid to the impact of such development on the flooding of vegetation especially forest stands. Both forested and un-forested terrestrial vegetation types were flooded (244 915 ha). Some islands were created and in addition portions of existing areas were flooded to form islands (74 075 ha) in the Main (Smallwood) Reservoir area. The flooded area of forest and un-forested land in the reservoir is $77 \%$ while the islands is 23 percent. The percentages of forested and un-forested areas lost to flooding are $64 \%$ and $36 \%$ respectively. The percent of commercial forests lost to flooding is approximately $1 \%$ and the non-commercial forests is $99 \%$ (with a total volume of approximately 10 million cubic meters of wood).
\end{abstract}

Keywords: New Reservoirs, Flooding, Boreal, Hydroelectric Power

\section{Introduction}

The growing demand for electricity (clean energy) in the World places a high priority on the development of the most suitable sites for hydroelectric power generation. However, the construction of such power plants and the establishment of the associated storage facilities (reservoirs with dykes) cause significant changes in the environment, often affecting extensive areas.

One of the major hydroelectric power developments took place at Churchill Falls (called the "Upper Churchill
Development”), Labrador, Canada, in the late 1960s and early 1970s. At that time, in general, not much attention was paid to the impact of such development on vegetation (especially on forest stands), then most of the research, concerning man made lakes, was directed towards the study of the aquatic ecosystems, the limnology, and the thermal characteristics in some of the recently established reservoirs (Oberg [1] and the Scientific Committee on Water Resources [2]). Other work related to flooding like plankton, chemistry and modeling productivity in this region is reported in Duthie and Ostrofsky 


\section{$[3,4]$ and Ostrofsky and Duthie [5].}

Environmental considerations were important during the construction of the Churchill Falls Power Project. In the early phases of construction of the storage facilities and the power house several investigations and base line studies, to monitor the environmental impact of the corresponding engineering interventions associated with the project, were initiated and funded by the Churchill Falls (Labrador) Corporation, abbreviated as [CF(L)Co]. Two of these studies dealt with the impact of flooding on vegetation in the Main also called the Smallwood Reservoir.

This current paper provides the background of the project starting with the distribution of the pre-flooded conditions related to vegetation and land cover types in and surrounding the Main Reservoir. Within the framework of the first study, a vegetation mapping and a general inventory was carried out to obtain information on the area distribution of the various forest stands and vegetation cover types flooded in the Main Reservoir and its vicinity (Bajzak [6]). A series of papers will focus special attention on the process to which submerged trees were subjected (Bruneau and Bajzak [7,8]) and other aspects related to flooding and de-watering effects on the terrestrial environment.

Currently there are plans to develop the "Lower Churchill Area” by establishing new power plants at Gull Island and at Muskrat Falls with associated reservoirs. These new plants would use the discharged water of the plant from Churchill Falls and the additional water collected from some of the Churchill River Basin. The information provided by these papers could have relevance to the environmental evaluation of these new developments in Labrador.

\section{Methodology}

In order to understand the nature of our studies the storage facilities will be described first, see Figure 1. There are 28 major drainage basins in Labrador, which have a mean annual runoff of some 600 - 700 mm with 190 billion cubic meters water discharge into the Labrador Sea (Water Resources Division [9]). The potential and actual hydroelectric power generating plants include the Menihek plant constructed in 1954, the Twin Falls plant located near Churchill Falls, the plant at Churchill Falls (Upper Churchill Development) and the Lower Churchill developments as well as other areas in Labrador. The Twin Falls plant produced electricity to the nearby Iron Ore Mining Company and to the construction of the Churchill Falls Development, however, it was mothballed in 1971. The principal storage facilities of the power plant are the Main (Smallwood) and the Ossokmanuan reservoirs. Besides the Main Reservoir other smaller reservoirs were also constructed. After the completion of the new reservoirs the water from the Ossokmanuan Reservoir was re-routed into the Main Reservoir.

The impact of the flooding in the Main Reservoir of the new plant was studied by the Faculty of Engineering and Applied Science of Memorial University of Newfoundland (Bajzak [6] and Bruneau and Bajzak [7,8]) but much of the information remained unpublished. Later the impact concerning snow melt runoff were also reviewed (Bajzak and Roberts [10] and Bajzak et al. [11]). First several earlier established test lines were revisited every year (1972,1973,1974), then later 5 year, (1977) and 10 year intervals. The study is currently active.

The construction of the dykes and control structures of the Main Reservoir was completed in 1972. There are 88 dykes in the system with an aggregated length of $62 \mathrm{~km}$ and with an average height of 9 meters. During the filling of the Main Reservoir, flow down stream of the Lobstick control structure was greatly reduced. With the impounding of the water in the Forebay reservoir (West and East Forebay) the flow down the original river was reduced significantly and the water running down Churchill Falls itself was almost completely eliminated.

Labrador has a landmass of some $288000 \mathrm{~km}^{2}$. It is represented by several sections of the Boreal Regions of Canada \{Section B13a and B31 (Rowe [13]), now Ecoregions 77 and 78 of Labrador (ESWG [14]\}, with smaller areas in Sections B12, (Meades and Roberts [15]). Wilton [16] used Hustich's [17] forest classification to sub-divide Labrador's forests into productivity classes using "understory" species. Later a bio-physical land classification system (Lacate [18]) was applied to describe the occurrence of various vegetation types in the Lake Melville area (Bajzak [19,20]). This land classification system evolved into the Canadian "Ecological Land Classification" system (ELC) and became the framework for environmental impact analysis and in resource management planning especially in forestry (Bajzak and Roberts [21,22], Roberts et al. [23-25] and Vanderveer [26]). Unpublished works of Bajzak, Bruneau, and Roberts for the Churchill Falls region (Newfoundland and Labrador Forest Management District 22) is currently being evaluated (Roberts and Deering [27]).

Most of the forests, affected by the Churchill Falls Power Development are made up of open and semi-open black spruce (Picea mariana, Mill.) stands with moss or dwarf shrub understory on well or moderately drained sites. On drier sites Cladonia and Cladina lichen forests of fire origin are common. On some of the better sites white birch (Betula papyrifera, Marsh) forms pure and mixed stands mainly as the result of disturbances due to fire and roads construction. Occasionally pure larch ( $\mathrm{La}$ rix laricina, K. Koch) stands can be found on poorly drained flat areas and along disturbed road ways. On wet 


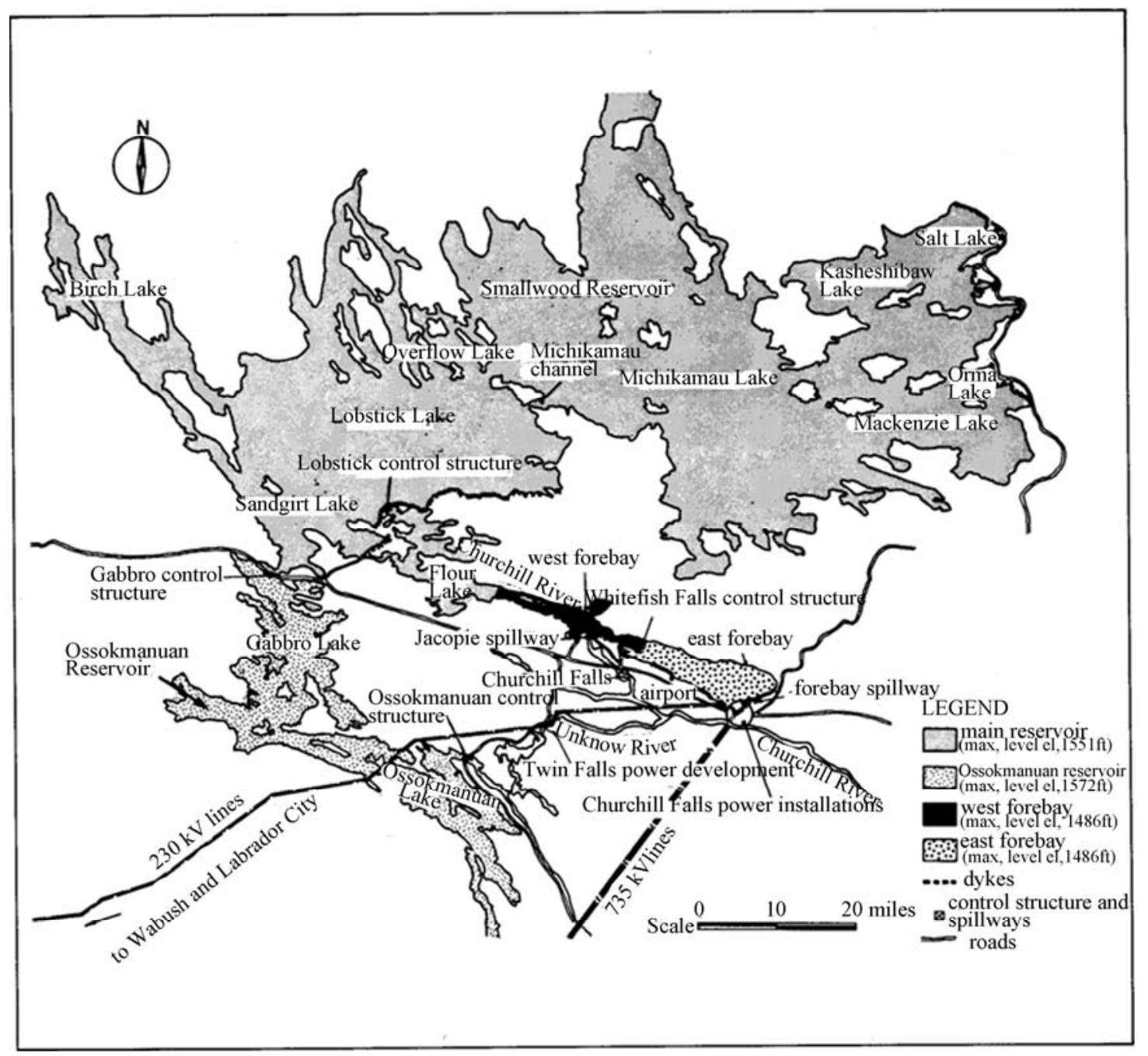

Figure 1. Water storage and control facilities (Churchill Falls Labrador Corporation Limited [12]).

bottom slopes Sphagnum moss and Ericaceous dwarf shrub black spruce forests occur grading into open peatlands with scattered trees. Almost every year extensive areas are burnt. Succession after fire is mostly to the black spruce pre-fire type on better sites. Poor black spruce scrub forest sites may degrade into Ericaceous barrens depending on fire severity. In this study the developed vegetation classification system was based on the experience gained in similar research projects by the authors in Newfoundland and Labrador. The following two major land cover types were recognized: Forests and Un-forested areas. These major types were sub divided as:

Forests :
1) Commercial
2) Non-commercial
1) Bogs, swamps, and fens
2) Rocks and shrub barrens
3) Recently burnt areas

Un-forested areas:

The forest classes were further sub-divided into soft wood, mixed wood, and hard wood based on the per- centage of soft wood and hard wood content (Newfoundland Forest Service [28]). A particular forest stand was considered commercial if the average height of trees was over $9 \mathrm{~m}$ and the average crown density was more than 55 percent.

The boundaries of the various vegetation cover types were established by aerial photo interpretation on black and white vertical aerial photographs, then they were transferred onto 1:50 000 Canadian NTS base maps and the areas of the various types were determined.

\section{Results}

The area distribution of the various vegetation cover type classes and the islands in the reservoir (when the reservoir is full) is shown by Table 1.

Using the figures in Table $\mathbf{1}$ the percentages of areas lost to flooding and of the islands in the Main Reservoir were calculated. The flooded area of forest and un-forest- 
Table 1. Distribution of Vegetation Cover Types and Islands (by area in ha) in the Main Reservoir.

\begin{tabular}{cll}
\hline VEGETATION TYPES & FLOODED & ISLANDS \\
\hline Forests & 156085 & 57085 \\
Non-commercial & 153895 & 53755 \\
soft wood & 153800 & 53660 \\
mixed wood & 40 & 55 \\
hard wood & 0 & 40 \\
Commercial & 2190 & 3330 \\
soft wood & 2130 & 3315 \\
mixed wood & 60 & 15 \\
hard wood & 0 & 0 \\
Un-forested areas & 88830 & 16990 \\
bogs, fens, marshes & 63445 & 2940 \\
rock and shrub barrens & 7165 & 4100 \\
recently burnt areas & 18220 & 9950 \\
TOTAL & 244915 & 74075 \\
GRANDTOTAL & & 318990 \\
\hline
\end{tabular}

ed land in the reservoir is $77 \%$ of the Grand Total (Table 1), while the islands is 23 percent. The percentages of forested and un-forested areas lost to flooding are 64\% and $36 \%$ respectively. The percent of commercial forests lost to flooding is approximately $1 \%$ and the non-commercial forests is $99 \%$ (with a total volume of approximately 10 million cubic meters of wood).

Extensive areas inside the rim of the reservoir are significantly affected by the water level fluctuation. In these areas the water level fluctuates seasonally and from year to year depending on the amount of precipitation and on the water requirement ("draw down") of the power plant. Some of the washed out trees and of woody debris accumulated on the shoreline (Figure 2) in considerable quantities and remain persistent for many years.

Based on a limited number of field sample plots a general forest stand volume table was prepared which can be used to determine the approximate total volume of

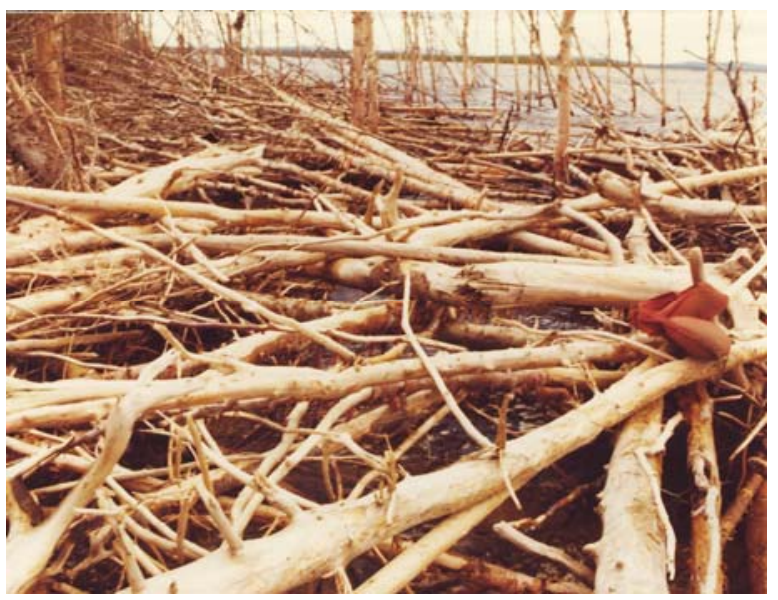

Figure 2. Accumulated Woody Debris. a forest stand. The mapping procedure yielded twenty maps. An example map is shown by Figure 3 .

This figure is a reduced copy of one of the maps produced. See Table 1 for the distribution of land cover types and islands. The thick winding black lines signify the border of the reservoir while the straight lines represent the approximate boundaries of the five mile wide strip from the borders outside the reservoir.

\section{Conclusions}

The vegetation classification and mapping was confined to the general area of the Main Reservoir, including the flooded areas, the islands in the reservoir, and a five miles wide strip outside the edge of the reservoir, as it was requested by the contracting [CF(L)Co]. A simple vegetation land cover classification was developed and the boundaries of the various classes were typed on vertical aerial photographs, field checked and then the boundary lines were transferred to 1:50 000 scale base maps. From these maps the approximate areas of the different cover types flooded and of the islands were determined. Although significantly large forested areas were flooded, the percentage of the commercial stands lost to flooding was minimal.

Most of the islands in the Main Reservoir were inaccessible, therefore, their flooding was considered not significant concerning wood utilization. Many trees were up-rooted in the fluctuating water level zone and most of these accumulated on the new shorelines and on the dykes. Some of the floating uprooted trees are a hazard at the control structures and at the power plant intake. Sheltered areas contain standing trees, still rooted, in the water. The accumulated logs and debris and standing trees in water look esthetically bad and can impair the movement of the wild animals. After 40 years some solid

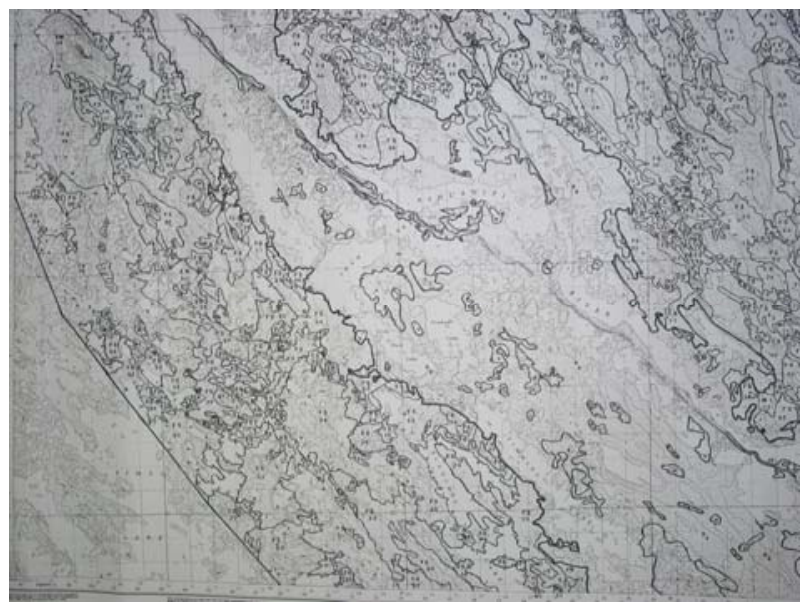

Figure 3. Vegetation Cover Type Map (Canadian 1:50 000 scale NTS 23I/4; Timmins Lake). 
debarked logs are still found through out the area on the dykes. The prepared maps of the various vegetation cover types, especially in the area of the five mile strips surrounding the reservoir, could be used in wildlife management plans and studies.

\section{Acknowledgement}

This research program was fully supported by the Churchill Falls (Labrador) Corporation in the past on contract to Memorial University. Later in-kind support was also provided and is gratefully acknowledged. We also thank the staff of the Water Resources Division of [CF(L)Co]. for some of the field logistics and equipment use both for summer and winter studies. In particularly we would like to acknowledge Dr. A. A. Bruneau's contribution to the project. We thank Natural Resources Canada, Canadian Forest Service and the Forest Ecology Centre, Provincial Department of Natural Resources for field, lab and storage facilities and support over a long period of time. We also thank Wayne T. Kelly, RPF, Director and William M. Clarke, RPF, Ecologist, Center for Forest Science and Innovation Forestry Branch Department of Natural Resources for additional logistics and publication support. Thanks are also due to the Faculty of Engineering and Applied Science, Memorial University for in-kind support after the contract obligations were fulfilled while one of the authors was employed by the University.

\section{References}

[1] E. L. Oberg, "Man Made Lakes - the Accra Symposium," Ghana University Press, Accra, 1969, p. 397.

[2] “Symposium on Man Made Lakes,” (Abstracts of Papers), Scientific Committee on Water Resources, Knoxville, 1971, p. 229

[3] H. C. Duthie and M. L. Ostrofsky, "Plankton Chemistry, and Physics of the Lakes in the Churchill Falls Region of Labrador," Journal of the Fisheries Research Board of Canada, Vol. 31, 1974, pp. 1105-1117.

[4] H. C. Duthie and M. L. Ostrofsky, "Environmental Impact of the Churchill Falls (Labrador) Hydro Electric Project - a Preliminary Assessment,” Journal of the Fisheries Research Board of Canada, Vol. 32, No. 2, 1975, pp. 117-125.

[5] M. L. Ostrofsky and H. C. Duthie, “An Approach to Modelling-Productivity in Reservoirs (Man Made Lakes)," Verhandlungen des Internationalen Verein Limnologie, Vol. 20, 1978, pp. 1562-1567.

[6] D. Bajzak, "Vegetation Classification and Mapping in the Main Reservoir of the Churchill Falls Hydro Electric Power Plant," Report Submitted to [CF $(L) C o]$., Faculty of Engineering and Applied Science Memorial University of Newfoundland, St. John's, NF, 1971, p. 46.
[7] A. A. Bruneau and D. Bajzak, "Effect of Flooding on Vegetation in the Main Reservoir, Churchill Falls, Labrador," Project Establishment Report, Faculty of Engineering and Applied Science Memorial University of Newfoundland, St. John's, NF, 1973, p. 27.

[8] A. A. Bruneau and D. Bajzak, "Effect of Flooding on Vegetation in the Main Reservoir, Churchill Falls, Labrador," Progress Report, Faculty of Engineering and Applied Science Memorial University of Newfoundland, St. John's, NF, 1975, p. 77.

[9] Water Resources Division, "Water Resources Atlas of Newfoundland,” Department of Environment and Lands Government of Newfoundland and Labrador, St. John's, NL. 1992, p. 79.

[10] D. Bajzak and B. A. Roberts, "Determination of Snow-Water Equivalent (SWE) Using Multi-Channel, Multi-Polarized, Multi-Temporal Synthetic Aperture RADAR (SAR)," Proceedings International Archives of Photogrammetry and Remote Sensing, Vienna, Vol. 21, part B7, 1996, pp. 36-42.

[11] D. Bajzak, B. A. Roberts and K. W. Deering, "Snow Hydrology Using Multy Channel, Multi-Polarized, MultiTemporal Synthetic Aperture RADAR,” International Archives of Photogrammetry and Remote Sensing, Budapest, Vol. 32, part 7, 1998, pp. 662-667.

[12] Churchill Falls (Labrador) Corporation Ltd., "The Churchill Falls Power Development Management and Construction Equipment”, Information Pamphlet (Paper Presented to the Earth Moving Industry Conference of the Society of Automotive Engineers, Central Illinois Section), Montreal, PQ, undated, p. 23.

[13] J. S. Rowe, “Forest Regions of Canada,” Environment Canada, No. 1300, 1972, p. 172.

[14] Ecological Stratification Working Group (ESWG), “A National Ecological Framework for Canada,” Research Branch Agriculture and Agri-Food Canada, Analysis Branch Centre for Land and State of the Environment Directorate Canada, Ottawa-Hull, 1995, p. 125.

[15] W. J. Meades and B. A. Roberts, "Review of Forest Site Classification Activities in Newfoundland and Labrador," The Forestry Chronicle, Vol. 20, No. 1, February 1992, pp. 25-33.

[16] W. C. Wilton, “The Forests of Labrador,” Canada Department of Forestry, Ottawa, Publication No. 1066, 1965, p. 72.

[17] I. Hustich, "On the Forest Geography of the Labrador Peninsula,” Acta Geography, Vol. 10, No. 2, 1949, pp. 2-63.

[18] D. S. Lacate, "Guidelines for Bio-Physical Land Classification," Canadian Forest Service Canada Department of Fisheries and Forestry, Ottawa, Publication No. 1264, 1969, p. 61.

[19] D. Bajzak, "Bio-Physical Land Classification, Labrador," Internal Report, Forest Research Branch Laboratory Canada Department of Forestry, St. John's, NF, No. 16, 1969, p. 12. 
[20] D. Bajzak, "Bio-Physical Land Classification of the Lake Melville Area, Labrador," Information Report, Newfoundland Forest Research Centre Canadian Forest Service, St’ John's, NF, NX-88, 1973, p. 115.

[21] D. Bajzak and B. A. Roberts, "Mapping Land Types for Forest Evaluation in the Lake Melville Area, Labrador, Canada," Extended Abstracts of the First IUFRO Workshop on Quantitative Assessment of Forest Sites with Special Reference to Soils, Swiss Federal Institute of Forest Research, Birmensdorf, 1985, pp. 4-5.

[22] D. Bajzak and B. A. Roberts, "Development of Ecological Land Classification and Mapping in Support of Forest Management in Northern Newfoundland, Canada," Journal of Environmental Monitoring and Assessment, Vol. 39, No. 1-3, 1996. pp. 199-213. doi:10.1007/BF00396145

[23] B. A. Roberts, D. Bajzak, K. W. Deering and E. F. Woodrow, "Ecological Land Classification in Support of Eco-System Management in Newfoundland. Forest Scenario Modelling for Eco-System management at Landscape Level,” G. J. Nabuurs, T. Nuutinen, H. Bartelink and M. Korhonen, Eds., EFI Proceedings, European Forest Institute, Wageningen, No. 19, 1998, pp. 305-311.

[24] B. A. Roberts, D. Bajzak, K. W. Deering and E. F. Woodrow, "Research and Training in Forest Land Classifica- tion in Support of Ecosystem Management in Newfoundland," Paper Presented at ASPRS-RTI Annual Conference, Tampa, 1998, pp. 855-859.

[25] B. A. Roberts, N. P. P. Simon and K. W. Deering, "The Forests and Woodlands of Labrador, Canada-Ecology, Distribution and Future Management," Ecological Research, Vol. 21, No. 6, 2006, pp. 868-880. doi:10.1007/s11284-006-0051-7

[26] D. G. Vanderveer, "The Surficial and Glacial Geology of Michikamau Lake, Central Labrador,” Final Report Newfoundland ERTS Project, Memorial University of Newfoundland, St. John's, NF, 1973, pp. 26-41.

[27] B. A. Roberts and K. W. Deering, with Contributions from D. Bajzak, V. Courtois, R. Parsons, N. P. Simon and A. R. van Kesteren, "Nitassinan (Labrador) Forest Ecology, Biodiversity Assessment and Cultural Study,” Paper Presented at Climate Change Impacts on Boreal Forest, VI International Conference Fairbanks (Program and Abstracts), 2007, p. 38.

[28] Newfoundland Forest Service, "Forest Inventory Statistics, Labrador," Department of Forestry and Agriculture Government of Newfoundland, St. John's, NF, 1975, p. 61. 